\title{
Policing Women's Bodies in an Illiberal Society: the case of Ireland
}

\section{Introduction}

The policing of women's bodies is now, as perhaps it has always been, an issue all around the world. Women's bodies and the relationship between women's bodies and culture, custom and honour, often generates for women profoundly problematic and in some cases lethal experiences. Female sexuality and the policing of it continually leads to the shaming of women, the ostracising of women, and the mutilation of women's bodies. The relating of female sexuality to notions of honour has long had serious implications for women. It could perhaps be argued that relating women's bodies and female sexuality to notions of honour is a function of the subjection of women. The conflating of women's bodies and female sexuality with honour has been a feature of Irish society as it has been a feature of many other societies.

While the policing of women's bodies is a global issue, and this special issue of Women \& Criminal Justice is important for that reason, the focus of this journal article is on the policing of women's bodies in Ireland. Ireland has a long history of an unhappy conference of women's bodies, the law, crime and reproduction. A great deal has been written about this history and there has been substantial debate about it. In particular, in recent years, the harsh and unforgiving treatment of unmarried mothers in Ireland has come into very sharp focus, and there has been in recent years a number of books published and films released which have addressed this topic. Sadly, as will be seen, the harsh treatment of women for the functioning of their bodies does not begin and end with the sad stories of the treatment of unmarried mothers. 
This journal article outlines the history of the policing women's bodies in Ireland in the context of law, crime and reproduction. It does this by means of three case studies. The first case study explores the policing of women's bodies in relation to sexuality. This case study considers both the historical and the contemporary experiences of women in order to provide a framework for understanding Ireland and the experiences of women in Ireland in relation to sexuality. The second case study focuses on reproduction and the policing of women's bodies in relation to reproduction. Ireland is unique in many respects in terms of women's experiences of reproduction, particularly in relation to the degree of social control exercised over women in Ireland with regard to reproduction, and the normalised nature in Irish society of that control. The third and final case study considers the policing of women's bodies in relation to abortion. This case study examines the controversy that surrounds abortion in Ireland and the legal framework that has developed around it. The journal article reveals the consequences of both the controversy and the legal framework in terms of the experiences of many women. Taken together, these three case studies provide an overview of the capacity, and indeed the readiness, that exists in Irish society to police women's bodies, and to do so particularly in relation to sexuality and reproduction. To begin with, in order to provide a theoretical framework for this article, a brief literature review is presented.

\section{Policing Women's Bodies: a brief review of the literature}

In many regards, women's experiences of the law and criminal justice is a history of the use of law and legal regulation to control and discipline women. From pre-Enlightenment witch trials ${ }^{\mathrm{i}}$ right through to the present day, it is the policing of women's bodies (Dobash et al, 1986), that brought women, and in many cases continues to bring them, into contact with the law and criminal justice systems. Women's bodies and the functionings of their bodies have featured, and they continue to feature prominently, in systems of justice and social control 
everywhere. See, for example, McAlister's, (2015), discussion of the policing of women's sexual and reproductive agency in the US, and 'the struggle for public control over the private spaces of women's bodies'. See also Kelly and Hoerl's (2015), article about the public scrutiny of women's vaginas, which, they write, functions implicitly and overtly to police women's sexual agency. See Chesney Lind and Shelden, (2014), for an exploration of the policing of girls, and the gendered and sexed nature of that policing experience. Writing about the policing of women and girls in Africa, Todd-Gher (2014), highlights the illegitimate criminalisation of women's and girls' sexual and reproductive conduct and identities. The issue of FGM (Female Genital Mutilation), is widely explored and discussed in the literature: Hodes et al (2015), state that an estimated 125 million women worldwide have undergone FGM. The United Nations Population Fund (UNFPA) states that FGM “is carried out as a way to control women's sexuality, which is sometimes said to be insatiable if parts of the genitalia, especially the clitoris, are not removed. It is thought to ensure virginity before marriage and fidelity afterward, and to increase male sexual pleasure".

Historically, criminology has always been pre-occupied with women's bodies, and early criminologists held profoundly misogynistic conceptions of women and female criminals, conceptions evident in their representations of female criminality (Quinlan, 2016). Through their particular focus on the body, these early criminologists generated a discourse of biologism that located the source of offending in the body (Lombroso and Ferrero, 1958 Ed., Pollak, 1961, and Thomas, 1967, see Quinlan, 2011a, 185-187). Daly wrote of the "spectre of biologism and body types that has long haunted criminology" $(2013,13)$. Contemporary evidence of misogyny and its biologism can be seen in rape myths, in their justifications for sexual violence. Victim blaming is one example of such justifications, more often directed at 
females, "she was asking for it"; another is the myth that the woman enjoyed it, a reference to "the unconscious desire that many women have to be raped" (see Monckton Smith, 2010, Hayes, Lorenz and Bell, 2013, and Garland, Branch and Grimes, 2016).

The misogyny evident in the work of early criminologists provides good evidence of the androcentric nature of the science. Androcentrism is the privileging of masculine interests, a masculine point of view, over feminine interests, a female point of view. It is a powerful and ingrained way of thinking and being, and it is slow, and reluctant, to dislodge. Connell's concept of hegemonic masculinity $(2005,77)$ is useful in terms of understanding the social relations that maintain masculine domination and feminine subordination. Hegemony is social, cultural and/or political dominance. Connell (2005) wrote of the mobile nature of hegemony, how, in order to self-perpetuate, it changes and adapts over time. She wrote of hegemony's currency, how it uses a current logic, a logic that is contemporary, that is current, to legitimate and perpetuate patriarchy.

One consequence of male hegemony in the sciences, as detailed by Daly and Chesney Lind $(1988,499)$, is the creation and broad acceptance of authoritative but inaccurate systems of knowledge on human behaviour. Daly and Chesney Lind (1988) explained the ways in which gender constructs, that is the network of behaviours and identities associated with masculinity and femininity, are socially constructed from relations of dominance and inequality between men and women. In the sciences, they wrote, depictions of women's natures have been made almost exclusively by men, specifically by white, privileged men. Through this gendered lens, women were stereotypically represented in terms of "their supposed biological and psychological nature” (Heidensohn and Gelsthorpe, 2007, 383). The focus on women's bodies and the androcentric perception and representation of the female body was further 
explained by Carlen and Worral (1987/1992), when they attributed the pathologising of women in criminology and criminal justice to perceptions of normal functionings of the female body, menstruation, pregnancy, childbirth, lactation, menopause, as sources of hormonal and psychological imbalance in women. There was a preoccupation in criminology with women's bodies, their bodily functions, sexual activity, and their psychological makeup, and it endured (see Flavin 2008, and Bernat and Holshuh, 2015).

Serious challenges to such androcentric scientific discourses developed in the late twentieth century and they were led by feminist scholars. Feminist criminology emerged as part of the second wave of feminism. Gelsthorpe and Morris (1988), wrote that it could be said that feminist criminology began in Britain with the publication in 1976 of Smart's book "Women, Crime and Justice”. Prior to the 1980s, as explained by Heidensohn and Gelsthorpe (2007, p. 383), women were largely ignored in studies of crime and delinquency, and when they were not ignored they were inserted into the criminological literature (Gelsthorpe and Morris, 1088, 228), the "add women and stir" approach (Chesney Lind, 1989).

The work of these pioneering feminist criminologists, among them Klein (1973) in the U.S., set, as Renzetti (2013) explained, an agenda for a new feminist criminology. By the end of the 1980s, Daly and Chesney Lind (1988), were marking a decade of feminist scholarship in criminology. We are reminded by Chesney Lind (2006), that prior to path-breaking feminist works on sexual assault, sexual harassment, and wife abuse, these forms of gender violence were ignored, minimized, and trivialized. Commenting on the fact that "theories, research methods and pedagogies" had been challenged across academic disciplines, Daly and Chesney Lind (1988), explained that feminist thought was emphasising a new social order in which women's experiences and ways of knowing were being brought to the fore. They 
wrote that disciplinary debates in some fields were, by the end of the $1980 \mathrm{~s}$, reflecting the impact of feminist thought, albeit uneven, across the disciplines.

Much early feminist research, as explained by Gelsthorpe and Morris, (1988, 98), consisted of exposes of discriminatory practices: researcher's seeking out and exposing sexism, (among them Worrall, 1981; Eaton, 1983, 1985 and 1986; Carlen, 1983; Edwards, 1984). These scholars demonstrated the complexity of the issue of women's treatment in criminal justice systems. Gelsthorpe and Morris (1988) wrote of the challenges early feminists criminologists mounted to beliefs and assertions of conventional criminology that women were treated more leniently than men in the criminal justice system. They wrote of a whole generation of feminist researchers questioning this. They highlighted $(1988,98)$, the disparity in criminal justice systems "between the rhetoric of leniency and the reality of practice".

Criminology is the study of crime, crime behaviour and social control (Renzetti, 2013, 2), and for most of the twentieth century, criminology, along with all other sciences, was male ordered. There was a gender divide. In that divide, maleness, the male gender and a masculinist perspective were privileged. Within this divide, the female and the feminine did not fare well. Although the science of criminology expanded, and into the twenty-first century most criminological textbooks contained chapters on the experiences of women, Daly (2000) wrote that male centrism in criminology was deep-seated. Daly welcomed the expansion of the field of study, and in particular the focus on the gendered and sexed character of offending and victimization, including studies of masculinities and masculine identities. However, it would, she wrote $(2000,87)$, be ironic, if this foregrounding of men and their activities resulted in the placing of women on the periphery "as cheerleaders and supporters of men". 
While much was won by feminist scholars, and in particular by the pioneering feminist scholars of those early years, feminists have for some time now been writing about the era of feminist backlash (see for example Faludi 1991, and Laidler and Mann, 2008). In America, this backlash was evident, Chesney Lind (2006, 9), wrote, in George Bush Jr.'s second presidential campaign, which included a moral values agenda designed to appeal to rightwing Christians, as well as a rolling back of the gains of the women's movement of the past century, including the re-criminalization of abortion. Chesney Lind $(1988,10)$ wrote that in this era of backlash, the formal system of social control (the law and criminal justice policies) plays a key role in eroding the rights of women. Ground gained in the second wave of feminism, was in many instances becoming ground lost in this era of backlash (Moore, 2007).

More recently, in light of the feminist backlash, and the persistence of male centrism in criminology, Renzetti $(2013,13-14)$, pondered the degree to which feminist criminology could contribute to a more progressive criminology. She asked if feminist criminology can have a transformative impact on mainstream criminology. Some feminists have despaired of a feminist transformation of criminology, despaired of challenging the resistance of mainstream, or malestream, criminology to a feminist transformation of criminology (Gelsthorpe, 2010). Some have highlighted a fundamental incompatibility between feminism and criminology and some put forward a strong case for feminists abandoning criminology altogether (see Smart, 1990). In defining feminist criminology, Renzetti $(2013,13)$ wrote that "feminist criminology is a paradigm that studies and explains criminal offending and victimization, as well as institutional responses to these problems, as fundamentally gendered, and that emphasizes the importance of using the scientific knowledge we acquire from our study of these issues to influence the 


\section{creation and implementation of public policy that will alleviate oppression and contribute to more equitable social relations and social structures".}

Gelsthorpe and Morris $(1988,97)$, wrote that, in essence, feminist perspectives are antipositivist, critical of stereotypical images of women, and within them the question of gender is central. Renzetti, (2013, 65), referencing Carlen (2011), advised that feminist criminologists, rather than wasting time on establishing opposition to mainstream criminology, and wondering whether colleagues are feminist enough or the right kind of feminist, should focus instead on doing a good job in terms of research, research conducted according to any one of an unlimited range of transparent research methods. There is certainly a need for continued critical engagement in terms of women's experiences in criminology and in criminal justice systems. Such critical engagement should produce useful research, research that documents the experiences of women. This journal article examines a particular experience of social control, that is, the policing of women's bodies in Ireland in the context of law, crime and reproduction. The hope is that the article makes a useful contribution in terms of documenting women's experiences, while critically examining the social and cultural forces generating and shaping those experiences.

\section{Three Case Studies}

This research project was developed using a case study approach. Case study is the most appropriate methodology for this research because it allows for an extensive and in-depth exploration of the phenomenon under investigation (Yin; 2014, 4, see also Quinlan, 2011b and 2015). This case study is comprised of three cases on the theme of policing women's bodies; the first case explored is sexuality, the second is reproduction, and the third is abortion. The utilisation of this methodological approach to study the policing women's 
bodies allows for a complex and in-depth exploration of that phenomenon. A selective timeline of key incidents is presented for each case. These timelines provide clear detail on the pattern of women's experiences over time.

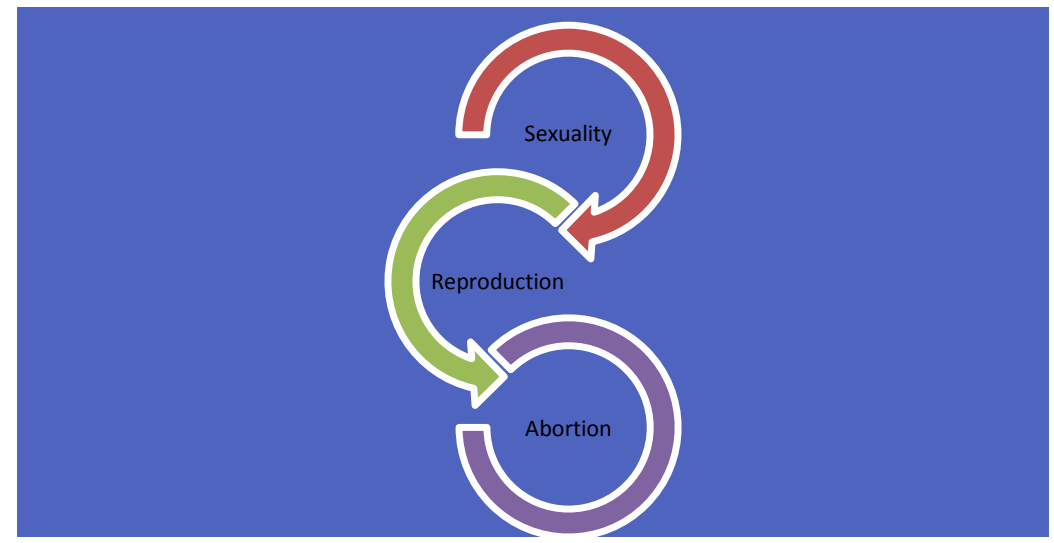

Fig. 1: Policing Women's Bodies, a case study

Each of the cases provides insight into the issues arising from the policing of women's bodies in Ireland, and the critical gender and justice issues that emerge from the study of these. Each of the cases is clearly interlinked however the approach used of developing separate cases for each facilitates a deeper and hopefully a richer study. At the same time, the case study methodology facilitates the emergence of a clear perspective on the practice of policing women's bodies in Ireland, and the experiences of women of their bodies being policed.

In the context of the policing of women's bodies, many women in Ireland have had very bleak experiences. Unfortunately, the bleak experiences of women in Ireland in terms of law, crime and reproduction, are mirrored in experiences of women in other parts of the world. Indeed in some time periods and places these experiences have been surpassed, in terms of their sheer savagery and brutality. The link between culture, religion and honour-based violence directed at women has been documented across the globe. The forces driving the experiences in Ireland are the same forces behind these experiences elsewhere. In Ireland the forces were, and they still are, the habitus of the people, formed by religion and a theocratic 
state, and articulated in notions of family honour and shame, rooted in misogynistic conceptions of appropriate femininity.

\section{Policing Women's Bodies: Sexuality}

The policing of women's bodies in Ireland in relation to sexuality has a long history. The contemporary experience can be traced back to the establishment of Magdalen Asylums in Ireland in 1765 , essentially to manage female sexuality, to rescue women from prostitution, to reform "fallen women" (Luddy, 1995, 2001, and Finnegan, 2001). From that point, the timeline, presented below, traces some of the key milestones in Irish history that shaped Irish culture and society in relation to the policing of women's sexuality. The timeline also sheds light on Irish culture and society in a way that, in part, explains how that culture was lived, and the implications of that lived experience for women.

The timeline begins with the establishment of Magdalen Asylums and moves on to the Contagious Diseases Acts, 1864-1866. The Contagious Diseases Acts were designed to help eradicate venereal disease, but used only against women (Quinlan, 2011a). Then there is the partitioning of Ireland, north and south, in 1920, and the establishment of the Irish Republic, essentially a theocratic Roman Catholic State. The Irish Constitution was enacted in 1937. It recognised, and to some degree established, the rightful and important role of women in the home "without which the common good could not be achieved" (article 4.1 of the Constitution).The next point on the timeline is the Commission on Emigration of 1948-1954, established by the Irish State and designed to examine the phenomenon of widespread emigration from Ireland; the Commission, in its report, acknowledged that at this time emigration from Ireland was a particularly female phenomenon (Travers, 1995a and 1995b). The next point on the timeline is the publication in 1970 of the Kennedy Report which, while 
noting that women were still at that time being held, with doubtful legal validity, in Magdalen Homes, called for instead a closed psychiatric facility for girls deemed to be "in moral danger".

\section{Government of Ireland Act}

(Partitioning Ireland)

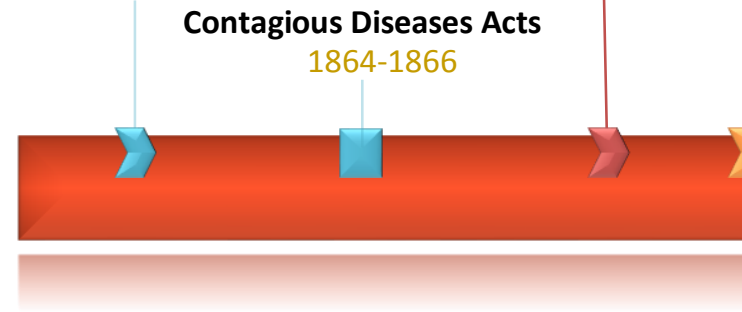

Fig. 2: Policing of Women's Bodies in Relation to Sexuality Timeline

Ireland joined the European Union (then the European Economic Community, the EEC) in 1973, and Irish culture and society began to change. The changes were swift and quite dramatic. These dramatic changes are illustrated in timeline where it ends, in 2015, with the enactment in Ireland of the Marriage Equality Act, which allows in law for civil marriage between gay and lesbian couples. The following paragraphs briefly explore the policing of women's bodies in relation to sexuality from the establishment of Magdalen Asylums in Ireland in 1765 to the enactment in law in Ireland of the Marriage Equality Act 2015.

Historically, women in Ireland had few employment opportunities. They were confined to the private sphere and lived very restricted vulnerable lives (Quinlan, 2011a, 13-33); unskilled, and responsible for babies and children, they were controlled in their communities by close observation and gossip. Historically, McLaughlin (2001, 81), suggests, economic factors were central to women's sexual expression. Women exchanged sexual favours within 
marriage for security. Some women were kept by the men with whom they had affairs, and were generally admired for being astute. Pauper women engaged in prostitution. Luddy (1995) wrote of the casual nature of prostitution in nineteenth century Ireland, explaining that many women engaged in prostitution as a temporary occupation, abandoning it when they could. Middle class women engaged in (unpaid) philanthropy, and joined organisations such as temperance societies and rescue missions, providing shelters for women in order to rescue them from drunkenness and prostitution (see Quinlan, 2011a, 15).

Magdalen Homes were at the centre of the system for the social control of female sexuality that developed in Ireland at the time (Luddy, 1995, 2001). Women were incarcerated in Magdalen Homes in Ireland for over one hundred years, from the late 1800s to the late 1900s (Quinlan, 2011a). The practice continued in Ireland until the 1970s, with Catholic nuns providing the most extensive network of Magdalen Homes, Asylums, Refuges or Laundries (Quinlan, 2011a, 53-54). Another institution, used between 1864 and 1886 to discipline women who offended sexual mores was the Lock Hospital (Geary, 2012). Lock Hospitals were used for the confinement of women deemed to be prostitutes and women found to be infected with venereal disease. Under the Contagious Diseases Acts 1864 and 1866, police were permitted to arbitrarily detain women on the streets, prostitutes, and in the case of the 1866 Act, every woman believed to be a prostitute, for medical examination for venereal disease, (Finnegan: 2001: 161, see also Quinlan, 2011a, 23). Infected women could be imprisoned in a Lock Hospital for up to nine months; if a woman refused to submit to medical examination she could be imprisoned for up to one month. The Acts operated only in areas of certain military camps in England and Ireland: in Ireland, in Cork, Cobh and the Curragh military camps. Luddy pointed out (1995: 109), that the acts, designed to eradicate venereal disease, applied only to women. 
Ireland changed dramatically over the twentieth century, and the first great change happened when Ireland was partitioned under the Government of Ireland Act, $1920^{\mathrm{ii}}$. Prior to and in the decades following partition in Ireland, the experiences of women in Ireland, north and south, were very similar in terms of the control and regulation of female sexuality. There was, as McCormack (2009) explained, considerable unity across religious and political spectrum in relation to female sexuality. McCormick (2009), explains that, in the twentieth century, the key societal issues in terms of the control of women on the island of Ireland related to: the experiences of women involved in prostitution; the experiences of women who sought shelter in Rescue Missions, including Mother and Baby Homes; the treatment of women who were suspected of having sexually transmitted disease; and the interaction of women with soldiers, British soldiers in the North and South of the island, and British and American soldiers in the North.

As the twentieth century developed, the Catholic Church, which grew in strength from the 1800s as the country underwent "a devotional revolution" (see Larkin, 1972), worked with the Irish State in conceptualising, creating and developing a Catholic theocracy, (Crowley and Kitchin, 2008). With the newly established Irish Republic, a project of nation building commenced. Crowley and Kitchin $(2008,355)$ wrote about the intensification and deepening of the disciplining structures of the Catholic Church through the pulpit and the school system, "using discourses of sin, shame, guilt, and familialism". These authors present a table detailing fourteen key reports and government acts concerning the regulation of sexuality (2008, 356): among these was the 1923 Local Government (Temporary Provisions) Act 1922, which provided a framework for dealing with unmarried mothers, proposing various methods for reforming "first offenders" and punishing "recidivists" and those who could not or would not be reformed. In 1924 and 1927 legislation was introduced to restrict women's right to sit 
on juries; in 1927 women's right to sit all examinations in the Civil Service was curtailed; in 1932 a marriage bar was introduced where married women were obliged to resign from all Civil Service positions; in 1935 the Government assumed the right to limit women's employment in any given industry; and in 1937 the Constitution defined women's role in the state exclusively in terms of the family, hearth and home (see Beaumont: 1999 and Scannell: 2001).

The primary concern of the Church was sexual morality, and they set about dealing with this by policing the morality of women. They did this deliberately and explicitly. The habitus of the society, the nation and the State was Catholic. Catholic habitus produced specific Catholic, religious and ethical, ways of being (Inglis: 1998 Ed.: 11). Valiulis: (1995: 172) wrote that an oppressive vision of the ideal of Irish womanhood, of which sexual purity was a primary characteristic, took hold. There was a particular devotion to Mariology, and through this the ideal of Irish womanhood was represented in motherhood, home and family (Quinlan, 2011a, 45). As the twentieth century progressed, for most women in Ireland controlling or attempting to control their own destinies, the only route available was emigration, and women emigrated from Ireland during these years in vast numbers. Emigration was such that in the mid twentieth century, a Commission on Emigration was established, (Travers: 1995a: 191, Travers: 1995b: 150). Travers outlined the conclusion of the Commission that young people, more than two thirds of them women, were emigrating to "escape the drabness of the average Irish village, with its frustrations, inhibitions and sterile outlook". The women who stayed conformed, led the charge for conformity, or they fell foul of the orthodoxies of the day. 
The habitus of the people is illustrated in the following vignette. In the late 1920's, a group of second-year teaching students at a teacher training college, Mary Immaculate Teacher Training College in Limerick, formed the "Mary Immaculate Modest Dress and Deportment Crusade” (MDDC), (see Ní Bhroiméil, 2008, 4), a crusade which proposed to put into practice what the bishops had preached. As Ní Bhroiméil details what was required, according to the students, was a "Crusade in the interests of womanly modesty" (Ní Bhroiméil, 2008, 7). Women's dress, in terms of a liberal feminine representation of self, was seen as threatening, and threatening in the early decades of the twentieth century even to the fragile emergent nation state in Ireland (Ní Bhroiméil 2008, 6). This MDDC initiative is used by historians, Ní Bhroiméil explains $(2008,4)$, “as an example of how women internalised the control of the Catholic Church and indeed sought to enhance and perpetuate it by their actions". She goes on to explain that Irish women are seen by historians as being generally accepting of Catholic social teaching, particularly in relation to sexuality. Their acceptance of this, and their efforts and actions in support of this, have been read as conformist, and even as collusion. Such collusion might be interpreted in terms of Meaney's (1991), explanation of women's engagement with, and adoption of, the roles provided for them as a route to power, the single and only route to power allowed to women within patriarchy.

A sense of the level of social control exercised over women in Ireland in the twentieth century can be gleaned, interestingly, from the numbers of women imprisoned over that century. For most of the twentieth century, the numbers of women in prison in Ireland declined. By 1960, in the Republic of Ireland, the daily Irish female prison population was down to 20, and by 1970, it was down to 14 (Quinlan, 2011a). In Northern Ireland, Armagh Gaol, until it closed in 1986, was the only women's prison (Quinlan, 2016). In the decades prior to 1970, it never accommodated more than twelve prisoners (Murray 1998, see also 
Quinlan, 2016). These very low numbers of women in prison in both the Republic of Ireland and Northern Ireland obfuscate to some degree the fact that women were being disciplined by mechanisms which were ostensibly outside of the criminal justice system. For example, in 1951, there was a daily average of 43 women in prison in the Republic of Ireland, and 2,003 women confined in institutions such as Mother and Baby Homes and Magdalen Laundries (Quinlan, 2011a, and O’Sullivan and O’Donnell, 2007, Quinlan, 2016, and Garrett, 2016).

In 1970, the Kennedy Report (the outcome of a government established enquiry into reformatory and industrial schools in Ireland) $(1970,39)$, noted that 70 girls between the ages of 13 and 19, girls deemed to be "in moral danger or uncontrollable", were being held by the courts in convent Magdalen Homes. Commenting on the doubtful legal validity of these detentions, the report noted that girls with recurring sexual offences, who were unwelcome in reformatory schools, were typically sent to Magdalen Homes The report criticised the "voluntary method of placement" where girls, committed by parents, family members, social workers, Welfare Officers, Clergy, or Gardaí (police), perhaps not aware of their rights, might remain in the convent for long periods. Many of the girls committed in this way, the report stated (The Kennedy Report, 1970, 39), remained in the convent all their lives. To replace this system of control, what was required, the report concluded $(1970,40)$, was a closed psychiatric facility for such teenage girls.

Towards the end of the twentieth century Ireland changed dramatically. From the 1970s onward the country developed and modernised. A key change came in 1973, when Ireland joined the European Union (then the European Economic Community, the EEC). This development led to the enactment in Ireland of equality legislation, bringing Ireland in line 
with European standards. Ireland became less isolated, and became more and more globally engaged and integrated. In addition, while the vast majority of people in Ireland, to the present day, culturally identify themselves as catholic (almost 4 million people from a population of 4.5 million, Central Statistics Office, (CSO), 2011 Census, Table 37), a great change has been wrought in terms of cultural practices. There has been a decline in religious practice, most notable in a sharp decline in the numbers going to Mass (Inglis, 2007), and the various sex abuse scandals involving catholic priests (Donnelly and Inglis, 2010, and Garrett, 2013), have contributed to the fundamental questioning and undermining of the authority of the catholic priest in Ireland, and to the secularisation of Irish society. With all this change, the change in sexuality has been most profound. This profound change was marked recently with the passage into law in Ireland of the $34^{\text {th }}$ Amendment to the Constitution (Marriage Equality) Act 2015, which enables gay and lesbian couples to marry in Ireland.

While all has changed, and changed utterly, to borrow from Yeats, it is perhaps in light of experience wise to be cautious. In her work on single women in Ireland, Byrne, $(2008,19)$, noting the "profound struggles to reform the gendered state" that took place in Ireland up to the 1990s. She wrote that once a gender contract is established, it proves difficult to alter (Byrne, 2008, 33). The gender contract in Ireland, she explained, endorsed male privilege and authority in political, social, economic, legal and family life, and deeply circumscribed women's roles and life options. As recently as 2012, Inglis and MacKeogh (2012), provided an interesting and instructive insight into the double standards that persist in Ireland in terms of women and sexuality. In this journal article, entitled "The double bind: Women, honour and sexuality in contemporary Ireland”, Inglis and MacKeogh (2012), describe media coverage of a 2009 court case in a provincial town in Ireland dealing with the sexual assault of a local woman by a local man. Through analysis of media coverage of the court case, the 
authors show how the legacy of Catholic Church teaching, within which the sexual honour of women lies in their innocence and subservience, still lingers, and although it is being replaced by portrayals of women as sexually equal and independent, in Ireland sexually independent women can still be portrayed in the media as threats to sexual moral order.

\section{Policing Women's Bodies: Reproduction}

The timeline below details some key milestones over the past one hundred years in Ireland in relation to the policing of women's bodies in the context of reproduction. As can be seen, the

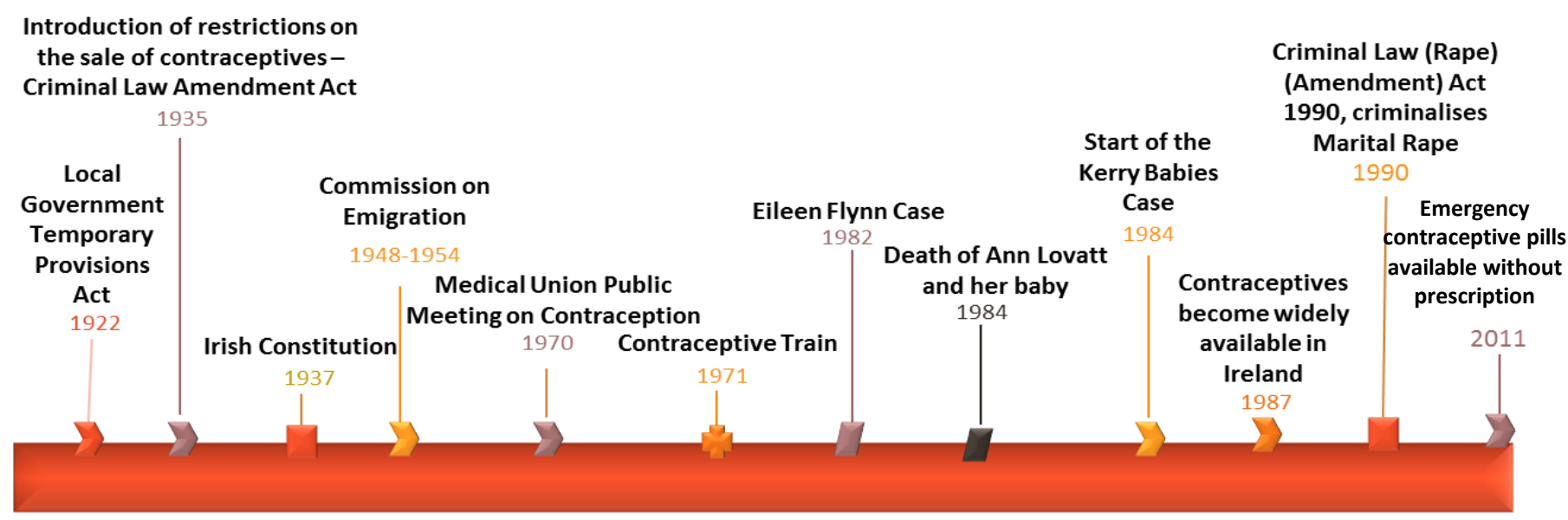

Fig. 3: Policing of Women's Bodies in Relation to Reproduction Timeline

timeline begins with the passing into law of the Local Government Temporary Provisions Act (1922), which, as explained earlier, provided a framework for dealing with unmarried mothers. The timeline goes on to highlight the introduction in law in 1935 of restrictions on the sale of contraceptives. The timeline then details the establishment of the Irish constitution in 1937. The period of the 1940s to the 1950s, arguably the bleakest period for women in modern Irish history, is marked in the timeline by the Commission on Emigration, 
established, as explained earlier, in response to very high levels of emigration from Ireland at that time. The timeline goes on to document the liberalisation of Ireland and Irish society. Three landmark events are detailed: the 1982 Eileen Flynn case; the tragic deaths in 1984 of Ann Lovatt and her baby son; and the Kerry Babies case which started in 1984. These three cases, as explained in the following paragraphs, were pivotal in the formation of contemporary Irish society.

The family is central to Irish life and history, and McCulloch (1991) explains how, from the great crisis of the mid-eighteenth century feminine, the family and the family structure shaped Irish life. ${ }^{\text {iii }}$ The family and its central position in the dominant ideology of Irish society was linked, he wrote, to rural fundamentalism and expressed in nationalist rhetoric and in a "desire to preserve a highly idealised rural past" (McCullagh, 1991, 200). The imperative was to protect and safeguard what were seen as national virtues, and this imperative was operationalised around the control of sexuality in order to defend the family and protect an idealised notion of family life. Within this aspiration, special measures were developed to help deal with "troublesome" populations, and principally, as explained earlier, unmarried mothers (Garrett, 2016).

The family became very much the focus of Irish life throughout the twentieth century, and particularly throughout the period of nation building. The centrality of the family in Irish life was enshrined in the Irish Constitution, enacted in 1937. The Catholic Church was most powerful in charting the development of the nation, with senior clerics developing, and local parish priests disseminating, the ethos and the mores of this catholic society. In this catholic society with its devotion to Mariology, explained earlier, the family was the means by which human reproduction was to be accomplished, and this was a critical issue for women in 
Ireland. In Ireland, pregnancy within the bonds of matrimony was sacred, holy, a gift from God. Pregnancy outside of marriage was a scandal, it was incontrovertible evidence of proscribed sexual activity, sexual activity which had taken place outside of the bonds of matrimony (see Leane, 1999).

There was great concern with the problem of unmarried mothers, and in response, a great complexity of structures was created and developed to deal with them. These structures were for the most part punitive in nature (see Quinlan, 2011a, 52-54). As has been explained, women emigrated from Ireland in huge numbers at this time, and for many women, pregnant and unmarried, escape the Britain was the best option (Garrett, 2016). Irish women in Britain, who were pregnant outside of marriage, could hide their pregnancy in anonymity; they could give birth and then place the baby for adoption. While such escape was the option chosen by large numbers of women, many unmarried pregnant women stayed in Ireland. Milotte (1997, 18), detailed how, between the 1920s and the 1970s over 100,000 babies were born in the Republic of Ireland to unmarried parents. An unmarried mother was a scandal in Ireland, but a scandal that could be secreted away. According to Millotte (1997: 156), nuns who ran the mother and baby homes and the Magdalen Asylums prided themselves on the stealth and concealment they could guarantee in terms of a pregnancy and birth, as any shadow of suspicion or scandal could jeopardise the girl's entire future. The secrecy, Millotte explains, protected the fathers of the babies, and prevented the mothers from demanding any rights they might have considered they had in relation to the babies.

The role of Magdalen Asylums in the secret export of Irish babies for adoption was documented by Milotte, (1997). He detailed the network of maternity hospitals, mother and baby homes, orphanages and industrial schools run by religious, generally nuns, in Ireland, 
all of which aimed for self-sufficiency through their farms, their laundries, their needlework and their bakeries, and all staffed "with fallen women". In these institutions, the harshest treatment was reserved for unworthy women, the "weak willed", "incorrigibles", "repeat offenders", "sexual deviants" and "prostitutes" (see Luddy: 2001, Finnegan: 2001, Crowley and Kitchin: 2008, O'Sullivan and O'Donnell, 2012, Garrett, 2016, and Quinlan: 2011a and 2016). This culture of punishing women, and only women, for pregnancy outside of marriage, and denying them status and rights as mothers, prevailed in Ireland until the late decades of the twentieth century.

When, in the early 1970s, Ireland joined the EEC, now the EU, and things began to change, Ireland opened up, became much more globally engaged, and began to develop a fresh new cosmopolitanism. While this is certainly true, three landmark events took place in the early 1980s that shocked and changed Irish society irrevocably. The first of these events occurred in 1982, when school teacher Eileen Flynn was fired from her job in a local convent secondary school for being pregnant outside of marriage. She was sacked from her post on grounds that she had rejected the school's norms of behavior, i.e. she was living unmarried, at the time, with the child's father. She took her employers to court in Unfair Dismissal cases, initially to an Employment Appeals Tribunal, and subsequently to the Circuit Court and then to the High Court. She lost every time (Hug, 1998, 122). The second event happened in January 1984 when a 15 year old convent school girl, Ann Lovett, who had hidden her pregnancy out of fear and shame, died shortly after giving birth, alone and in secret, on a dark day in January, at an open-air grotto, a Marian shrine. The baby she gave birth to, a son, also died (Maguire, 2001). The third event began in April 1984, when the body of a new born baby was found on a beach in Kerry, and, later, a second baby's body was found on a farm fifty miles away. The police investigation into these events, which became known as the 
Kerry Babies case, was so controversial, because of the way the woman at the centre of the case was treated, that this woman became a feminist symbol in Ireland, a powerful representation of what happens to a woman in Ireland when she transgresses moral codes (Maguire, 2001, 338, McCafferty, $20102^{\text {nd }}$ Ed.).

These three key events facilitated a public airing of anger, shame and sorrow in Ireland, and they provided, in part, the impetus necessary to force change. As Maguire (2001, 336-337) explains, there developed a very broad public debate on catholic ideals of family and family life and the realities of many people's lives, their sexual behaviors and attitudes. The debate was public, heated, and frequently bitter, and through this broad and heated debate local communities in Ireland were forced to redefine right and wrong. A new tolerance developed and a more sexually permissive society emerged. The 1970s and 1980s in Ireland can be viewed as a period of transition from traditional ideals of both the family and the role of women in Irish society. Clearly, the transition was painful. There was a reluctance to embrace a different way of life. Local crises, as detailed above, forced change in Ireland, it may be said, as much as the macro changes at governmental and European levels.

Another major change came for women in Ireland, and women everywhere, in the form of contraception. In 1970, Galligan (1998, 145-146), details, the Irish Medical Union held a public meeting on family planning. The meeting, Galligan writes, was packed, it received a great deal of press coverage, and it was addressed by, among others, a young senator, Mary Bourke, who shortly afterwards married and changed her name to Robinson. Four years later, the issue of family planning was politicised when, in 1974, Senator Robinson and two other Senators attempted to introduce to government a new Private Members Bill reforming family planning laws (Galligan, 1998, 146); the attempt failed, as did three further attempts in the 
following five months. The reform of family planning laws in Ireland, Galligan explains, (1998, 146) became a contentious and a divisive topic, and the Women's Liberation Movement in Ireland began to hold public protests on the issue, and protests took place outside catholic churches during Sunday masses. A defining moment in the campaign to legalise contraception in Ireland came in 1971, when a group of feminists took the train to Belfast (Ferriter, 2012, 441), to buy condoms and other illegal contraceptives to bring them back to Dublin to challenge Customs officials. They were allowed, waving their contraceptives, to pass through Customs in Dublin without challenge, and the media coverage of the exercise, which became known in Ireland as the Contraceptive Train (Galligan, 1998, 146, and Murphy-Lawless and McCarthy, 1999), caused great embarrassment to government, as well as great hilarity in some sectors of public opinion.

The following paragraph details the legislative framework governing the use of contraceptives in Ireland, and the liberalization of that legislation. The introduction in 1935, of a ban on the importation and sale of contraceptives, through Section 17 of the Criminal Law Amendment Act, 1935, as explained by Canavan $(2012,13)$, left Irish people with three alternatives, abstinence, coitus interruptus, or the rhythm method, as methods of family planning. This situation prevailed in Ireland until the 1960s. The contraceptive pill became available in the 1960s, but only as a menstrual cycle regulator. In 1973, a Supreme Court decision provided for the right for contraceptive use in the context of marital privacy, Canavan $(2012,13)$ explains; it took a further six years before restrictive legislation on the sale of contraceptives was introduced, and a further fourteen years before contraceptives became generally available in Ireland, in 1987. The liberal sale and use of contraceptives in Ireland developed slowly and controversially. As detailed in the timeline at the start of this 
section, emergency contraceptive pills became available without prescription in Ireland in 2011.

\section{Policing Women's Bodies: Abortion}

This final section deals with the policing of women's bodies in Ireland in the context of abortion. The timeline below details some of the key landmarks related to abortion in Ireland. As can be seen, the timeline begins with the Offences Against the Person Act of 1861, which criminalised women who "procure a miscarriage", and also made it a crime to assist a woman "to procure a miscarriage". There was no change in legislation then for over one hundred years, until 1983, when the first of three referenda was held in Ireland on the issue of abortion. The timeline highlights the cases of individual women, the $\mathrm{X}$ Case, the $\mathrm{C}$ Case, the D Case, and the Y Case, (letters were used to preserve the anonymity of the women at the centre of each of the cases), which all helped shape the legal framework governing abortion in Ireland. The timeline also highlights the tragic death, in 2012, of Savita Halappanavar. All of these cases and issues are explored in detail in the following paragraphs.

A key starting point in this exploration of the policing of women's bodies in Ireland in the context of abortion is the referendum of 1983, the "ban on abortion" referendum (MacMillan, 1992, see IFPA, Abortion in Ireland: Legal Timeline, for a history of the legal framework on abortion in Ireland). In this referendum, which was bitterly fought and hugely divisive, the Eighth Amendment of the Constitution (Article 40.3.3) was inserted into the Irish Constitution. It reads "The State acknowledges the right to life of the unborn and, with due regard to the equal right to life of the mother, guarantees in its laws to respect, and, as far as practicable, by its laws to defend and vindicate that right". With the passing of this referendum, the Irish State recognised the equal right to live of the foetus, the unborn child, 
with the expectant mother. This clause in the constitution has had serious and sometimes profoundly tragic implications for women in Ireland.

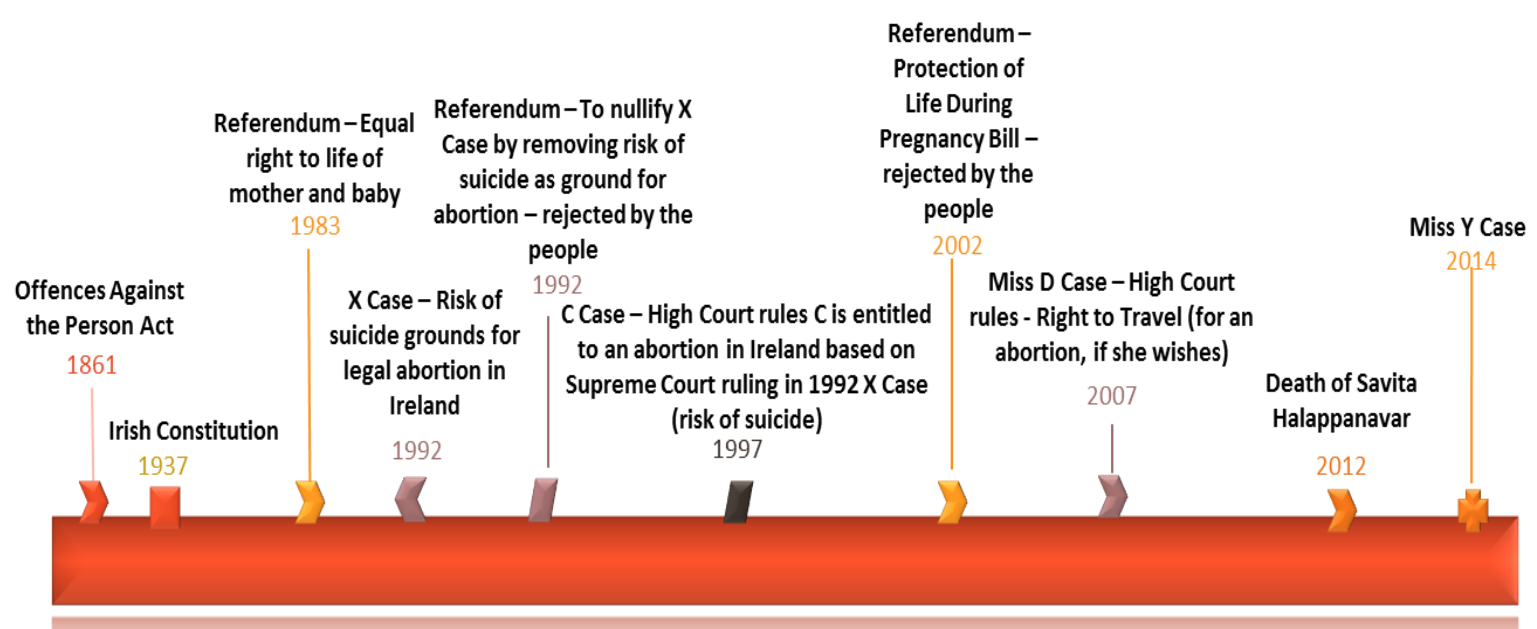

Fig. 4: Policing of Women's Bodies in Relation to Abortion Timeline

In 1992, the X case came before the Supreme Court in Ireland. The X case concerned a fourteen year old girl, pregnant as a result of rape, and at risk of suicide. The second referendum, driven by the $\mathrm{X}$ case and held in 1992, upheld the ban on abortion, but, with the passing of the Thirteenth Amendment of the Constitution of Ireland, specified that the prohibition of abortion would not limit freedom of travel in and out of the state. Following this vote, women were free to travel from the State, even if the travel was for the purpose of procuring an abortion. In reality, and practicably, how could they be stopped? Following the referendum women in Ireland had both a right to travel and a right to seek information on abortion; before this, court injunction's had been issued stopping the distribution of information on foreign abortion clinics. Women in Ireland generally travelled, and they still do, to the UK for abortions (Smyth, 1992). Abortion has been legal in the UK since 1967 (see Marie Stopes, What is the UK law on abortion?). The referendum also asked the Irish people 
if they wished to roll back the X Case judgment in order to remove suicide as grounds for abortion in Ireland. This was rejected by the people, and the threat of suicide remained grounds for abortion in Ireland.

The third referendum, held in 2002, which proposed to remove the threat of suicide as a grounds for abortion and increase the penalties for helping a woman have an abortion, was rejected by the Irish people. The fact that these referenda were held at all is a tribute to the power of the anti-abortion lobby in Ireland. With these three referenda, 1983, 1992, 2002, (for detail on the referenda, voter turnout etc, see $\underline{w w w . E l e c t i o n s I r e l a n d . o r g), ~ a ~ w i d e ~ r a n g e ~ o f ~}$ statutory instruments were enacted in law, and a number of policy and practice initiatives were developed (for more information see www.ifpa.ie).

There is currently in Ireland a growing political movement around the issue of a repeal of the Eighth Amendment to the Constitution (inserted into the Constitution following the first referendum, as detailed above) (see Lord, 2015). Some of the grounds on which the Repeal the $8^{\text {th }}$ movement rest are that: the amendment infringes on the human rights of women in Ireland and goes against international human rights norms; it criminalises those who selfadminister abortion pills in Ireland; it discriminates against those who cannot travel to obtain abortions; and it does not reflect present public opinion in Ireland (see Abortion Rights Campaign http://www.abortionrightscampaign.ie/repealthe8th/ for more information). The table below, created from data on the IFPA (Irish Family Planning Association) website (www.ifpa.ie), details the numbers of Irish women accessing abortion services in England and Wales over the ten years from 2005 to 2014.

Table 1: Numbers of Irish Women Accessing Abortion in the UK 2005-2014 


\begin{tabular}{|l|l|l|l|l|l|l|l|l|l|l|}
\hline Year & All ages & Under 16 & $\mathbf{1 6 - 1 7}$ & $\mathbf{1 8 - 1 9}$ & $\mathbf{2 0 - 2 4}$ & $\mathbf{2 5 - 2 9}$ & $\mathbf{3 0 - 3 4}$ & $\mathbf{3 5 - 3 9}$ & $\mathbf{4 0}$ and over & $\begin{array}{l}\text { Not } \\
\text { stated }\end{array}$ \\
\hline 2014 & 3,735 & 21 & 84 & 168 & 918 & 865 & 799 & 586 & 294 & - \\
\hline 2013 & 3,679 & 21 & 90 & 213 & 911 & 884 & 746 & 558 & 256 & - \\
\hline 2012 & 3,982 & 32 & 92 & 223 & 1,082 & 964 & 777 & 549 & 263 & - \\
\hline 2011 & 4,149 & 37 & 111 & 295 & 1,109 & 1,051 & 755 & 534 & 257 & - \\
\hline 2010 & 4,402 & 41 & 115 & 303 & 1,181 & 1,137 & 789 & 565 & 271 & - \\
\hline 2009 & 4,422 & 38 & 155 & 291 & 1,234 & 1,164 & 759 & 523 & 258 & - \\
\hline 2008 & 4,600 & 27 & 140 & 344 & 1,296 & 1,232 & 841 & 499 & 221 & - \\
\hline 2007 & 4,686 & 47 & 147 & 350 & 1,387 & 1,282 & 790 & 474 & 209 & - \\
\hline 2006 & 5,042 & 39 & 194 & 419 & 1505 & 1370 & 824 & 491 & 200 & - \\
\hline 2005 & 5,585 & 39 & 173 & 482 & 1759 & 1451 & 860 & 541 & 280 & - \\
\hline
\end{tabular}

As can be seen from the table, the women's ages range from under 16 years of age to 40 years of age and over, and although the numbers have steadily dropped for all ages over the ten years, except for the over 35 years of age and older women, the numbers for these age groups are increasing. Travelling to the UK for an abortion is not an option for every woman. The women who do travel for an abortion have the money to do so; they pay for return flights to the UK; accommodation in the UK, and they have to pay for the service (the NHS pays for almost all of the abortions carried out in the UK for women resident in the UK, see Marie Stopes, Abortion in the UK).

Abortions in the UK tend now to be medical rather than surgical procedures, and this may account for the reducing numbers of women travelling to the UK; women may be selfadministering abortion pills in Ireland. This may also account for the fact that the numbers of women 35 years of age and older travelling for abortion continue to rise. It could be that the women in this age range travelling for abortion are perhaps not as computer literate as younger women, and consequently would not buy abortion pills over the internet. It is more likely however that rising numbers of women in this age range can be accounted for by the fact that the self-administration of abortion pills is a criminal offence in Ireland, and women in this age range have the financial resources needed to travel for abortion. The IFPA "Abortion and Ireland Fact File" details that, for example, in 2009, 1,216 illegal packets of 
abortion inducing drugs were seized by Irish Customs. The Fact File also details that for the years 1980 - 2009, an estimated 147,912 women resident in Ireland have had an abortion abroad, (IFPA Abortion and Ireland Fact File).

In more recent years, a number of events have occurred which highlight the inadequacy of the legal and ethical frameworks surrounding abortion in Ireland. In 2007, there was the Miss D case (see Miss D, my story). Miss D, a 17 year old, in the care of the state, was pregnant and she was told that her baby suffered from anencephaly, a disease which meant that the baby would be born with part of its brain missing. The HSE (Health Service Executive) went to the High Court to stop Miss D travelling to the UK for an abortion. The High Court ruled that the case was about the right to travel, and not about abortion, and ruled that Miss D could, if she wished, travel to the UK for an abortion. The HSE accepted the High Court decision (RTE, 2007).

In 2012, in another tragedy, 31 year old dentist, Savita Halappavanar, an Indian national, and her 17 week-old unborn baby, died from septicaemia in hospital in Ireland (Lentin, 2013). This case, the Savita Halappavanar case, was reported widely in the media, including international media. Savita had been told that she would miscarry and had requested, repeatedly, a termination of the pregnancy. This request was refused because there was a foetal heartbeat, and in Ireland, under the constitution, there is an equal right to life for the foetus and the expectant mother. In 2013, a report was issued by the Health Information Quality Authority in Ireland (HIQA) (see Patient Safety Report, 2013), dealing with patient safety, and with the end of life experience of Savita Halappavanar, The findings of the investigation "reflected a failure in the provision of the most basic elements of patient care to Savita Halappavanar”. 
A third tragic case occurred in 2014, when a young woman arrived in Ireland on March $28^{\text {th }}$ and claimed asylum as a refugee. A timeline of the Miss Y Case is presented in The Irish Times, the paper of record in Ireland. (see Timeline of Miss Y Case, The Irish Times). The facts of this case, as detailed in the timeline, are as follows. A routine health screening established that she was pregnant. She became very distressed. She said that no one could know that she was pregnant, and she said that the pregnancy was a result of rape. All options were explained to the young woman, called Miss Y to preserve her anonymity. Her legal status as an asylum seeker meant that there were implications for her in terms of travel from the state for an abortion. A number of professionals, counsellors and medics, as well as the staff of NGO's, become involved with the case, and time passed.

On June $17^{\text {th }}$, Miss Y was seen by a doctor at Spirasi (an NGO dedicated to supporting migrants and survivors of torture, which operates under the auspices of The Spiritans, a congregation of Catholic priests), who found that she was not "actively suicidal"; risk of suicide being grounds for abortion in Ireland. On July 17th, Miss Y registered with a new GP and requested an abortion. She was referred for psychiatric assessment. She was by this time 22 weeks pregnant. She attended this GP again on July 22nd, and said that she would rather die than continue with the pregnancy. She was referred for psychiatric assessment and admitted to a psychiatric hospital as a voluntary patient. There was evidence of suicidal intent, and she was transferred to a maternity hospital. On July $23^{\text {rd }}$ she was told that it was too late for an abortion.

On July $24^{\text {th }}$ Miss Y refused food and fluids. The next day she was assessed by a consultant psychiatrist who recorded that she was detainable under the Mental Health Act, that she wanted the baby dead. Miss Y continued refusing food and fluids. On August $2^{\text {nd }}$ the HSE (Health Service Executive) applied to the High Court for permission to sedate her and rehydrate her. Permission was granted. She was still refusing food and fluids on August $6^{\text {th }}$ 
2014, when a caesarian section was performed, she was 26 weeks pregnant, and a baby boy was delivered. The baby was taken into care. On August $13^{\text {th }}$ Miss Y was discharged from hospital. The baby remains in care.

Most recently, the experiences of women who faced criminal charges this year, 2016, charged with abortion offences, can be added to the list of shocking events and tragic experiences. In one case, a twenty-one year old who bought pills over the internet to bring about an abortion received a suspended prison sentence in Northern Ireland (The Guardian Newspaper, April $4^{\text {th }}, 2016$, see Evans and O'Brien, 2015, for an examination of a similar case in Australia, the Cairns abortion trial); Northern Ireland has limited access to abortion, (see Marie Stopes, Abortion in the Republic of Ireland, Can I travel to Northern Ireland for an abortion?) In this case, the police had been notified of the circumstances of the abortion by the woman's housemates at the time. When the police arrived at the house, they found the remains of a male foetus in a bin outside the house. The woman was prosecuted under the Offences Against the Person Act 1861 (detailed in the timeline outlined at the start of this section). She was given a three month suspended sentence. Another woman came before the courts in Northern Ireland on similar charges on April 6 ${ }^{\text {th }}, 2016$; charged with helping her daughter access abortion pills, she is to stand trial (Independent, April $7^{\text {th }}$, 2016).

A number of rallies to protest these prosecutions have been held, in Belfast and elsewhere around the world, and a number of groups have organised, among them the We Trust Women group in the UK which has organised a campaign to remove relevant sections of the 1861 Act, (http://www.wetrustwomen.org.uk/about-the-campaign/). Amnesty International Northern Ireland has called for an end to this "grotesque spectacle" of women before the courts (Amnesty International, 2016). Amnesty has developed a campaign and produced a report on abortion in Ireland entitled "My Body My Rights”, and they developed a powerful campaign slogan "She is Not a Criminal" (see Amnesty International, 2015). In 2015, the UN Committee on Economic, Social and Cultural Rights (CESCR) criticised Ireland's restrictive abortion laws; and in 2016, during the combined third and fourth periodic review of Ireland's 
implementation of the UN Convention on the Rights of the Child, the UN Committee on the Rights of the Child (CRC) expressed a number of concerns regarding the impact of Ireland's abortion laws on girls' human rights. One of the recommendations to government called for the provision in Ireland of safe access to abortion and abortion after-care services (IFPA Abortion in Ireland: Legal Timeline). Access to legal and safe abortion care is an issue for women globally (see Casas and Vivaldi (2014), for an examination of the issue of abortion in Chile, Brookman-Amissah (2012), for an explanation of the need for access to comprehensive abortion care in order to save women's lives in Africa, and ).

\section{Conclusions}

This journal article details the experiences of women in Ireland in relation to sexuality, reproduction and abortion. As explained at the start, it is not a happy history. It is a history of punishment, of shame, of social exclusion and exile. It is a history of struggle. The journal article documents the suffering of women in Ireland in relation to sexuality, reproduction and abortion. It details the powerful social forces, within the theocratic state that Ireland was and to some degree still is, that shape women's experiences. It provides some insight into the workings of Irish patriarchy. The shocking experiences of women in Ireland are revealed through each of the landmark events highlighted in the three timelines presented in this journal article. The experiences of many women in Ireland are truly shocking. Experiences such as these must be used to pave the way for change, used to liberalise the structures governing the lives of all women. Let their suffering set us free. This journal article was written to record and document experiences endured by many women in Ireland. It is dedicated to these women and to the memory of their struggles.

\section{References}

Abortion Rights Campaign, Petition Repeal the $8^{\text {th }}$, 
http://www.abortionrightscampaign.ie/repealthe8th/ (accessed 13.07.2016).

Amnesty International, (2015), She is not a criminal,

https://www.amnesty.ie/sheisnotacriminal (accessed 13.07.2016).

Amnesty International, (2016), Northern Ireland: Grotesque Spectacle of Women Before the Courts Must End, as Second 'Abortion Pills' Trial Starts, https://www.amnesty.ie/news/northern-ireland-\%E2\%80\%9Cgrotesquespectacle\%E2\%80\%9D-women-courts-must-end-second-\%E2\%80\%98abortionpills\%E2\%80\%99-trial-star (accessed 13.07.2016).

Beaumont, C., (1999), Gender, citizenship and the state in Ireland 1922-1990. in David Alderson, Fiona Becket, Scott Brewster and Virgina Crossman (Ed.s), Ireland in Proximity: History, Gender, Space, Pub. Routledge.

Bernat, F.P., and Holshuh, C.S., (2015), Is there a war on women or are females fine? An Examination of Sex, Gender and the Criminal Justice Field, Women \& Criminal Justice, Vol. 25, Iss. 1-2, pp. 6-10.

Brookman-Amissah, E., (2012), Saving women's lives in Africa through access to comprehensive abortion care, The European Journal of Contraception and Reproductive Health Care, 17, 241-244.

Byrne, A., (2008), Single Women in Ireland, in Women on Their Own: Interdisciplinary Perspectives on Being Single, Edited, Bell, R.M., and Yans, V., Pub. Rutgers University Press.

Canavan, J., (2012), Family and Family Change in Ireland: An Overview, Journal of Family 
Issues, 33(1), $10-28$.

Carlen, P., (1983), Women's Imprisonment, London, Routledge and Kegan Paul.

Carlen, P., Hicks, J., O’Dwyer, J., Christina, D., and Tchaikovsky, C., (1985), Criminal Women, Pub. Polity, Cambridge.

Carlen, P. and Worral, A., (eds), (1987/1992), Gender, Crime and Justice, Pub. Open University Press, Milton Keynes.

Carlen, P., (2011), Against evangelism in academic criminology: For criminology as a scientific art, in M. Bosworth and C. Hoyle, (eds.), What is Criminology, Oxford, Oxford University Press.

Casas, L., and Vivaldi, L., (2014), Abortion in Chile: the practice under a restrictive regime, Reproductive Health Matters, Vol. 22, Iss. 44, pp. 70-81.

Central Statistics Office (CSO), 2011 Census, Table 37, http://www.cso.ie/en/media/csoie/census/documents/census2011pdr/Pdf_8_Tables.pd f (accessed 13.07.2016).

Chesney Lind, M., (2006), Patriarchy, Crime, and Justice, Feminist Criminology in an Era of Backlash, Feminist Criminology, Vol. 1, No. 1, 6-26.

Chesney Lind, M., and Shelden, R.G., (2014), $4^{\text {th }}$ Ed., Girls, Delinquency and Juvenile Justice, Wiley.

Connell, R.W., (2005), Masculinities, Pub. Polity. 
Constitution of Ireland - Bunreacht na hÉireann,

http://www.taoiseach.gov.ie/eng/Historical_Information/The_Constitution/ (accessed 13.07.2016).

Crowley, U., and Kitchin, R., (2008), Producing 'decent girls': governmentality and the moral geographies of sexual conduct in Ireland (1922-1937), Gender, Place and Culture, Vol. 15, No. 4, 355 - 372.

Daly, K., (2000), Gender, Crime and Criminology, chapter in Handbook of Crime and Punishment, M. Tonry, (ed), pp. 85 - 108.

Daly, K., (2013), Different Ways of Conceptualising Sex/Gender in Feminist Theory and Their Implications for Criminology, Chapter One in Girls, Women and Crime:

Selected Readings, edited by Meda Chesney Lind and Lisa Pasko, Pub. Sage.

Daly, K., and Chesney Lind, M., (1988), Feminism and Criminology, Justice Quarterly, 5, $497-38$

Dobash, R.P., Dobash, R.E., and Gutteridge, S., (1986), The Imprisonment of Women, Pub. Blackwell Inc., New York.

Donnelly, S., and Inglis, T., (1010), The Media and the Catholic Church in Ireland; Reporting Clerical Child Sex Abuse, Journal of Contemporary Religion, Vol. 25 , iss. 1 , pp. $1-19$.

Eaton, M. (1983), Mitigating Circumstances: Familiar Rhetoric, International Journal of the Sociology of Law, 11, 385-400.

Eaton, M. (1985), Documenting the Defendant, in J. Brophy and C. Smart (eds), Women in Law. London, Routledge and Kegan Paul. 
Eaton, M. (1986), Justice for Women? Family, Court and Social Control, Milton Keynes, Open University Press.

Edwards, S. S. M., (1984), Women on Trial, Manchester, Manchester University Press.

Elections Ireland, www.electionsireland.org (accessed 13.07.2016).

Evans, B., and O'Brien, E., (2015), The Cairns abortion trial: Language, deviance, and the 'spoiled identity', Journal of Sociology, Vol. 51, No. 3, pp. 755-768.

Faludi, S, (1991) Backlash: The Undeclared War against Women, Pub. Vintage, London.

Ferriter, D., (2012), Occasions of Sin: Sex and Society in Modern Ireland, Profile books.

Finnegan, F., (2001), Do Penance or Perish: A Study of Magdalen Asylums in Ireland, Pub. Congrave Press, Piltown, Co. Kilkenny, Ireland, Pub. Oxford University Press (2004).

Flavin, J., (2009), Our Bodies Our Crimes, The Policing of Women's Reproduction in America, New York University Press.

Galligan, Y., (1998), Women and Politics in Contemporary Ireland: From the margins to the mainstream, Pub. Pinter, London and Washington.

Garland, T. S., Branch, K. A., and Grimes, M. (2016). Blurring the lines: Reinforcing rape myths in comic books, Feminist Criminology, 11, 48-68.

Garrett, P.M., (2013), A “Catastrophic, Inept, Self-Serving” Church? Re-examining Three Reports on Child Abuse in the Republic of Ireland, Journal of Progressive Human Services, Vol. 24, Iss. 1, pp. 43-65.

Garrett, P.M., (2016), Unmarried Mothers' in the Republic of Ireland, Journal of Social 
Work, 0(0), 1-8.

Geary, L.M., (2012), The Wages of Sin Is Death: Lock Hospitals, Venereal Disease, and Gender in Prefamine Ireland, in Gender and Medicine in Ireland 1700 - 1950, Preston, M.H., and Ó hÓgartaigh, M., Syracuse University Press.

Gelsthorpe, L., (2010), Women, Crime \& Control, Criminology \& Criminal Justice, 10(4), pp. $375-86$.

Gelsthrope, L., and Morris, A., (1988), Feminism and Criminology in Britain, British Journal of Criminology, 28 (2), 93-110.

Hayes, R. M., Lorenz, K., \& Bell, K. A. (2013). Victim blaming others: Rape myth acceptance and the just world belief, Feminist Criminology, 8, 202-220.

Health Information and Quality Authority (HIQA), (2013), Patient Safety Investigation Report published by Health Information and Quality Authority, https://www.hiqa.ie/press-release/2013-10-09-patient-safety-investigation-reportpublished-health-information-and-qualit (accessed 13.07.2016).

Heidensohn, F, and Gelsthorpe, L., (2007), Gender and Crime, in The Oxford Handbook of Criminology, $4^{\text {th }}$ Ed., edited by Maguire, M., Morgan, R., and Reiner, R., Pub. Oxford University Press.

Hodes, D., Armitage, A., Robinson, K., Creighton, S.M., (2016), Female genital mutilation in children presenting to a London safe-guarding clinic: a case series, Archives of Disease in Childhood, 101, pp. 212-216.

Hug, C., (1998), The Politics of Sexual Morality in Ireland, Pub. Palgrave Macmillan. Independent, (April $7^{\text {th }}$, 2016), Second Northern Irish woman faces jail under abortion laws 
after helping daughter have termination,

http://www.independent.co.uk/news/uk/crime/second-northern-irish-woman-to-standtrial-on-abortion-charges-a6972726.html

IFPA (Irish Family Planning Association), Abortion in Ireland: Timeline, https://www.ifpa.ie/Hot-Topics/Abortion/Abortion-in-Ireland-Timeline

Inglis, T., (1998), Lessons in Irish Sexuality, Pub. University College Dublin Press.

Inglis, T., (1998 Ed.), Moral Monopoly: The Rise and Fall of the Catholic Church in Modem Ireland, Pub. University College Dublin Press.

Inglis, T., (2007), Catholic Identity in Contemporary Ireland, Journal of

Contemporary Religion, Vol. 22, Iss. 2, pp. 205-220.

Inglis, T., and MacKeogh, K., (2012), The double bind: Women, honour and sexuality in contemporary Ireland, Media, Culture \& Society, 34 (1), 68-82.

Irish Family Planning Association (IFPA), https://www.ifpa.ie/ (accessed 13.07.2016).

Irish Family Planning Association (IFPA), Abortion in Ireland Timeline www.ifpa.ie http://www.ifpa.ie/Hot-Topics/Abortion/Abortion-in-Ireland-Timeline (accessed 13.07.2016).

Kelly, C.R., and Hoerl, K.E., (2015), Shaved or Saved? Disciplining Women's Bodies, Women's Studies in Communication, 38, 141-145.

Klein, D., (1973), The Etiology of Female Crime: The Criminology of Deviant Women, Pub. Houghton Mifflin, Boston.

Laidler, K.J., and Mann, R.M., (2008), Anti-Feminist Backlash and Gender Relevant Crime Initiatives in the Global Context, (Editorial), Feminist Criminology, Vol. 3, No. 2, $79-81$.

Larkin, E., (1972), The Devotional Revolution in Ireland, 1850-75, The American 
Historical Review, Vol. 77, No. 3, pp 625-652.

Leane, M., (1999), Female Sexuality in Ireland 1920-1940: Construction and regulation, unpublished $\mathrm{PhD}$ thesis, University College Cork. https://cora.ucc.ie/handle/10468/545 (accessed 13.07.2016)

Lentin, R., (2013), A Woman Died, Feminist Review, 105, pp. 130-136.

Lombroso, C., and Ferrero, W., (1958 ed.), The Female Offender, Pub. Wisdom Library, New York.

Lord, S., (2015), The Eighth Amendment: planting a legal timebomb, in The Abortion Papers Ireland: Volume 2, Attic Press.

Luddy, M., (1995), Women and Philanthropy in Nineteenth Century Ireland, Pub. Cambridge, Cambridge University Press.

Luddy, M., (2001), Abandoned Women and Bad Characters: Prostitution in Nineteenth Century Ireland, in The Irish Women's History Reader, Alan Hayes and Diane Urquhart (eds) Pub. Routledge.

MacMillan, G., (1992), The Referendum, the Courts, and Representative Democracy in Ireland, Political Studies, XL, 67-78.

Maguire, M.J., (2001), The Changing Face of Catholic Ireland: Conservatism and Liberalism in the Ann Lovatt and Kerry Babies Scandal, Feminist Studies, Vol. 27, No. 2, (Summer), $335-358$.

Marie Stopes, Abortion in the UK, https://www.mariestopes.org.uk/women/abortion?gclid=CMCFwdCtxs8CFSIo0wodU $\underline{\text { wNbw }}$

Marie Stopes, What is the UK law on abortion? https://www.mariestopes.org.uk/women/abortion/abortion-facts/what-uk-law-abortion Marie Stopes, Abortion Law in the Republic of Ireland, Can I travel to Northern Ireland for 
an abortion?, https://www.mariestopes.org.uk/overseas-clients-

abortion/irish/abortion-and-law/abortion-law-republic-ireland

McAlister, J.F., (2015), Policing Sexual and Reproductive Agency in US Public Culture, Women's Studies in Communication, 35, 125-128.

McCafferty, N., (2010) (2 ${ }^{\text {nd }}$ ed), A Woman to Blame: the Kerry Babies Case, Pub. Ireland, Attic Press.

McCormick, L., (2009), Regulating Sexuality: Women in Twentieth Century Northern Ireland, Manchester, Manchester University Press.

McCulloch, C., (1991), The Tie that Blinds: Family and Ideology in Ireland, The Economic and Social Review, Vol 22, No. 3, April, 199-211.

McLoughlin, D., (2001), Women and Sexuality in Nineteenth Century Ireland, in A. Hayes and D. Urquhart, (eds), The Irish Women's History Reader, London, Routledge.

Meaney, G., (1991), Sex and the Nation: Women in Irish Culture and Politics, Pub. Ireland, Attic Press.

Milotte, M. (1997), Banished Babies: The Secret History of Ireland's baby Export Business, Pub. New Island Books, Dublin.

Miss D, my story, (2007), The Irish Independent Newspaper, http://www.independent.ie/irish$\underline{\text { news/miss-d-my-story-26288744.html }}$

Monckton Smith, J., (2010), Relating Rape and Murder: Narratives on Sex, Death and Gender, Pub. Palgrave Macmillan.

Moore, D., (2008), Feminist Criminology: Gain, Loss and Backlash, Sociology Compass, Vol. 2, Iss. 1, pp. 48-61.

Murphy-Lawless, J., and McCarthy, J., (1999), Social Policy and Fertility Change in Ireland The Push to Legislate in Favour of Women's Agency, European Journal of Women's Studies, Vol. 6, No. 1, 69-96. 
Murray, R, (1998), Hard Time-Armagh Gaol 1971-1986, Pub. Mercier Press.

Ní Bhroiméil, Ú., (2008), IMAGES AND ICONS: FEMALE TEACHERS'

REPRESENTATIONS OF SELF AND SELF-CONTROL IN 1920s IRELAND,

History of Education Review, Vol. 37, No. 1, pp. 4-15.

O’Sullivan, E., and O’Donnell, I., (2007), Coercive Confinement in the Republic of Ireland:

The waning of a culture of control, Punishment and Society, 9(1), 27-48.

O’Sullivan, E., and O’Donnell, I., (2012), Coercive Confinement in Ireland: Patients,

Prisoners and Penitents, Manchester, Manchester University Press.

Patient Safety Report Published by Health Information and Quality Authority (HIQA) (2913),

https://www.hiqa.ie/press-release/2013-10-09-patient-safety-investigation-report-

published-health-information-and-quality (accessed 13.07.2016).

Pollak, O., (1961), The Criminality of Women, Pub. A.S. Barnes.

Quinlan, C., (2011a), Inside: Women in Prison in Ireland, Past and Present, Pub. Irish Academic Press.

Quinlan, C., (2011b), Business Research Methods, Pub. South Western Cengage.

Quinlan, C., Babin, B., Carr, J., Griffin, M., and Zikmund, W.G., (2015), Business Research Methods, Pub. South Western Cengage.

Quinlan, C., (2016), Women, Imprisonment and Social Control, in The Routledge Handbook of Irish Criminology, D. Healy, C. Hamilton, Y. Daly, and M. Bulter, (eds), Pub. Routledge.

Renzetti, C., (2013), Feminist Criminology, Pub. Routledge.

RTE (2007), Miss D can travel for abortion: Court

http://www.rte.ie/news/2007/0509/88757-abortion/ (accessed 13.07.2016).

Scannell, Y., (1988), The Constitution and the Role of Women, pp. 123-36 in Brian Farrell (Ed.) De Valera's constitution and ours, Pub. Gill and Macmillan, Dublin. 
Smart, C., (1990), Feminist approaches to criminology or postmodern woman meets atavistic man, in Feminist Perspectives in Criminology, Gelsthorpe, L., and Morris, R., (eds), pub. Open University Press.

Smyth, A., (1992), The Abortion Papers, Ireland, Attic Press.

The Guardian Newspaper, (April, $\left.4^{\text {th }}, 2016\right)$ Northern Irish Woman Given Suspended Sentence Over Induced Abortion, https://www.theguardian.com/uknews/2016/apr/04/northern-irish-woman-suspended-sentence-self-induced-abortion

The Kennedy Report (1970), Reformatory and Industrial Schools System Report, chaired by District Justice Eileen Kennedy, The Stationary Office, Dublin, Ireland.

The Irish Times, Timeline of Miss Y Case, October 4, 2014, http://www.irishtimes.com/news/social-affairs/timeline-of-ms-y-case-1.1951699 (accessed 13.07.2016).

The Thirty-fourth Amendment to the Constitution (Marriage Equality) Act 2015 http://www.oireachtas.ie/viewdoc.asp?fn=/documents/bills28/acts/2015/a34th15.pdf (accessed 13.07.2016).

Thomas, W.I., (1967), The Unadjusted Girl, Pub. Harper and Row, New York. Timeline of the Miss Y case, The Irish Times, http://www.irishtimes.com/news/social$\underline{\text { affairs/timeline-of-ms-y-case-1.1951699 }}$

Todd-Gher, J., (2014), Policing bodies, punishing lives: The African Women's Protocol as a tool for resistance of illegitimate criminalisation of women's sexualities and reproduction, African human Rights Law Journal, Vol. 14, No. 2, http://www.scielo.org.za/scielo.php?script=sci_arttext\&pid=S199620962014000200020

Travers, P., (1991a), Emigration and Gender: The Case of Ireland, 1922-1960, in Chattal, Servant or Citizen: Women's Status in the Church, State and Society, Mary O'Dowd 
and Sabine Wichert (Ed.s), Pub. The Institute of Irish Studies, The Queen's

University, Belfast.

Travers, P., (1991b), There was nothing for me there: Irish female emigration 1922-71, in

Irish Women and Irish Migration, Patrick O’Sullivan (Ed.), Pub. Leicester University

Press.

UNFPA (United Nations Population Fund) Female Genital Mutilation (FGM) Frequently

Asked Questions, http://www.unfpa.org/resources/female-genital-mutilation-fgmfrequently-asked-questions\#why

Valiulis, M., (1995), Neither Feminist nor Flapper: The Ecclesiastical Construction of the Ideal Irish Woman, in The Irish Women's History Reader, Alan Hayes and Diane Urquhart (eds) Pub. Routledge.

We Trust Women, the campaign to decriminalise abortion across the UK,

http://www.wetrustwomen.org.uk/ (accessed 13.07.2016).

Worrall, A., (1981), Our of Place: Female Offenders in Court, Probation Journal, 28, 3, pp

$90-93$.

Yin, R.K., (2014), Case Study Research, Design and Methods, Pub. Sage.

\footnotetext{
' Famous burnings of Irish women for witchcraft include the condemnation for witchcraft and heresy of Dame Alice Kytler by Bishop Richard Ledrede and the burning of her maid Petronella in Kilkenny in the 1320's, (Brennan: 2000:37); and the burning to death in 1895 by her husband, family and neighbours of twenty-six year old Bridget Cleary, believed to be a changeling left by fairies who had taken the real Bridget away, (Bourke: 1999). Bourke, (1999: 33-34), details many nineteenth-century newspaper accounts in Ireland of similar incidents, most of them involving elderly women, burned, beaten, drowned or otherwise tortured and/or killed in order 'to put the fairy out'. Irish society was superstitious, fearful of fairies and watchful for changelings, and it remained this way until the country began to develop economically in the late decades of the 1800's, when the people became moral and civilised, and the Catholic Church assumed power (see Inglis, 1998).

ii This took place in 1921. An independent Irish Republic was established in twenty six counties in the south of Ireland. Six counties in the north of Ireland remained part of Britain.

iii The major watershed in 19th-century Ireland was the Great Famine. This was caused primarily by the increasing size of the population and the response of family farmers to it. The population stood at 5,000,000 in 1800. By 1841 it had risen to $8,000,000$. When a male family member got married, the father sub-divided his
} 
holding and gave a certain portion to the married son. Families were large and holdings generally small and this led to the fragmentation of holdings. By 1841 two-thirds of the population lived on the land and one half of farms were less than five acres. Such holdings could only sustain the growth of a basic crop like the potato and, as the potato could not be efficiently stored, the rural population was vulnerable to crop failure. Crop failure happened in 1845 and again in 1846. The result was widespread hunger and death. By 1851 the population was almost 2,000,000 lower than in 1846 and at least 1,000,000 had died of starvation. The effect on rural life was traumatic. It prompted a major readjustment in the family system. The sub-division of land and the pattern of family life it supported was no longer an economic option. It was abandoned and replaced by an inheritance system organised around the stem family. This, to simplify, meant that one son was chosen to inherit the entire farm - the principle of impartibility of inheritance. Though in theory the chosen heir was the eldest son, there is some evidence that in Ireland this was not always the case (see O Grada, 1980, also Lyons, 1973, pp. 51-52). The rest of the family were however, effectively, dispossessed. Although provision was to be made for them, in the Irish context this, in reality, meant emigration. 